\title{
Worshipers and Warriors
}

\author{
White Lotus Influence on the Nian Rebellion
}

ELIZABETH J. PERRY

University of Michigan

In examining China's two-thousand-year history of peasant revolt, one is struck by continuities in both location and organizational style. For century upon century, rebellions tended to erupt in similar form in particular geographical areas. To be sure, variations in demands, leadership, fighting strategy, and so on did occur in response to changing historical circurmstances. Yet the overriding impression is of a tenacious persistence of certain patterns of revolt in particular geographical regions.

One such hotbed of peasant unrest was the Huai River valley, scene of the first great popular revolt in Chinese history. Since that ancient beginning by Wu Guang and Chen Sheng in 209 B.C., the area has witnessed countless peasant upheavals. Memories and traditions were passed down through the ages to keep alive a consciousness of the possibility and method of resistance to oppression. What is the explanation for this continuity? What mechanisms served to transmit the experience of revolt from one generation to the next?

MODERN CHINA, Vol. 2 No. 1, January 1976

(C) 1976 Sage Publications, Inc. 
Certainly considerable credit must be given to the role of oral literature in this process. It is sometimes claimed that peasants are unrevolutionary because they lack a sense of history. Modern revolutions, according to this argument, must be led by an educated class with a notion of historical mission. Actually, however, the peasantry too had its interpretation of the past and of its role in it. In the absence of a writing system, peasants depended upon oral history, reinforced in song, proverb, and verse, to preserve and perpetuate significant events. Information which could not be stored in books for future reference had to be remembered by the human mind if it were not to be lost forever. The transfering of this knowledge was an extremely important aspect of the upbringing of children in peasant societies. ${ }^{1}$

Recently Chinese historians have devoted much attention to this question of peasant oral history. Thanks to their efforts, we are now in possession of a growing collection of folk songs and folk tales dealing with peasant revolt. ${ }^{2}$ The literature on the Nian and Boxers in particular is useful as a partial introduction to the collective memory of peasant rebels on the North China plain. The stories are rich in practical matters of strategy and tactics. Oral literature served to transmit from one generation to the next knowledge of how to recruit, organize, and fight.

Revolutionary traditions were thus perpetuated verbally by local story tellers and older relatives. At the same time, we must wonder if there was not a more formal institutional context through which such transfer occurred. A connection can be suggested between peasant unrest in the Huai River valley and the centuries-old existence of the White Lotus Society in that region. This secret society, whose origins are obscure, provided inspiration for countless rebellions in the area. In the Standard Histories of the Ming Dynasty it is recorded that toward the end of the Yuan dynasty a White Lotus adherent by the name of Han Shan-tang proslaimed the imminent arrival of the Maitreya Buddha. In the Huai valley, followers flocked to Han's cause, 
declaring him the rightful emperor. An army of red-turbaned peasants was raised and revolt broke out. While this initial uprising was quickly suppressed, other aspirants arose to lead the so-called Red Army. Finally a Buddhist monk, Zhu Yuan-zhang, succeeded in overthrowing the Mongols and establishing the Ming dynasty.

The victory proved a mixed blessing for the White Lotus Society, however. Soon outlawed by the new emperor, Ming Tai-zu, the group found itself once again thrust into a role of opposition. Throughout five centuries of Ming and Qing rule, the White Lotus Society was repeatedly associated with popular uprisings in the Huai River valley.

\section{FOLK RELIGION OF THE WHITE LOTUS SOCIETY AND NIAN DEOLOGY}

The White Lotus was a syncretic sect, combining elements of Buddhism, Taoism, and Manicheanism. Its practices included medical healing, sitting and breathing exercises, martial arts, and the chanting of spells and charms. Socially speaking, the Society was a haven for poor and disaffected peasants of the North China plain. It provided a source of material aid and an otherworidly refuge from their difficuit iives.

The fact that this association managed to retain its spirit of resistance down through the ages suggests its importance as a vehicle of continuity. Were peasant rebellions in the Huai River region heirs to a legacy of White Lotus principles and practices? More specifically, what connections can be established between the secret society and that massive Huai valley revolt of 1851-1868, the Nian Rebellion? Chinese historians have in recent years devoted considerable attention to a discussion of the origins and consequences of peasant insurrections. It is thus of interest to examine their findings in an attempt to explore the possibility of a relationship between the White Lotus and the Nian.

As might be expected, there is much divergence of opinion among mainland Chinese historians over the role of secret societies in peasant uprisings. Such diversity arises in part from 
the complex position of classical Marxism with regard to the role of religion in revolutionary movements (Harrison, 1969: 165-166). While characterizing religion as the "opiate of the people," Marx also pointed out the inevitable importance of religion in feudal and Oriental societies. In such societies, mass struggles necessarily take on a religious tone; in fact religion may be the only means of instigating revolt under these conditions.

Many Chinese scholars have sought to overcome the apparent contradiction between these two views by distinguishing between the oppressive religion of the upper classes and the potentially dynamic creeds of the peasantry. Somewhat akin to Redfield's notion of "little" and "great" traditions, this view holds that the religious beliefs of the lower classes were capable of inspiring resistance to the ruling elite. The theory is not entirely unlike that of traditional Confucians who also recognized "heterodox" (xie) doctrines as a serious political threat. Orthodox Neo-Confucians of the Ming and Qing periods were acutely aware of the intimate connection between folk religion and peasant uprisings. Thus such teachings and related organizations were outlawed by repeated imperial edicts. ${ }^{3}$

This inspirational role of folk religion is much like that which Engels (1966: 54) ascribes to heterodox Christianity in The Peasant War in Germany.

A totally different character was assumed by that heresy which was a direct expression of the peasant and plebeian demands, and which was almost always connected with an insurrection. This heresy, sharing all the demands of middle-class heresy relative to the clergy, the papacy and the restoration of the ancient Christian church organization, went far beyond them. It demanded the restoration of ancient Christian equality among the members of the community, this to be recognized as a rule for the middle-class world as well. From the equality of the children of God it made the implication as to civil equality, and partly also as to equality of property.

Thus equality, as a religious principle, was socially significant to the German peasantry.

According to the research of Richard Chu (1967), notions of equality also played an important role in the ideology and 
practice of the White Lotus Society. The theoretical basis for this equality lay in the sect's creation myth. Legend held that life had been formed by the intervention of the Eternal Mother, Wu sheng lao mu. The fact that all people were regarded as children of the Eternal Mother opened the way for equality between the sexes. In many White Lotus movements throughout the Ming and Qing dynasties women were active as fighters and group leaders. The first sizable White Lotus uprising during the Ming was led by a Shandong (Shantung) woman, Tang Sai-er (Chu, 1967). Noted for her prowess in Taoist magical arts, Tang mobilized a revolt that swept across the province in 1420 .

In addition to sexual equality, there is some evidence of cooperative economic activities among White Lotus members. During the Lin Qing uprising of the early nineteenth century, members donated alms to neighboring areas in Shandong. There are also scattered suggestions that true equalization of property may have been carried out upon occasion. In any event, there were at least certain welfare measures to aid the poorest participants in the struggles (Chu, 1967). In much the same way that religion was socially significant to the peasant in Germany, the principles and ideology of the White Lotus Society were socially significant to the peasant in China.

Having established the potential usefulness of a secret society such as the White Lotus in inspiring mass revolt, what concrete support exists for the claim that it was in fact a source of inspiration to the Nian Rebellion? For the Nian we unfortunately have very little documentation of any developed system of ideology. The historian Fan Wen-lan (1962: 156-157) does point to one Nian myth as evidence of a rudimentary notion of class struggle. According to Fan, members of the Nian orally transmitted a story dealing with a time when Confucius was in difficult straits. On the verge of starvation, Confucius is said to have dispatched his disciple to borrow grain from Fan Dan, a man known for his poverty who went hungry as a matter of course. Because Confucius' life was at stake, Fan Dan generously lent out the meager amount of grain that constituted his family's entire supply. Later Confucius became powerful and 
acquired wealth, but he did not acknowledge his debt to Fan Dan. The Nian claimed that all scholars (the landlord class) were offspring of Confucius, whereas the Nian were descendants of Fan Dan. The descendants of Fan naturally had the right to demand restitution for the old debt from the descendants of Confucius. In Fan Wen-lan's view, this legend contained a salient element of class struggle which was powerfully suggestive to the poverty-stricken peasants of the Huai River valley.

While Fan's suggestion is an intriguing one, he cites no source for his conjecture. ${ }^{4}$ Furthermore, the anti-Confucian myth does not appear in any of the published Nian folk stories or songs. In short, with what little is known about Nian ideology, it is impossible to establish a definite connection with the White Lotus on this level.

\section{ORGANIZATIONAL EVTEENCE OF WHITE LOTUS-NLAN CONNECTTON}

Instead it seems sensible to look for an organizational rather than an ideological linkage. Secret societies acted as meeting places for the destitute. They thus performed the important function of organizing peasants on a basis other than the family. Perpetuated by ritual, these groups managed to maintain their identity for generation upon generation, existing as potential pools of recruits for insurgent activities. This sort of continuity is similar to the role attributed by Engels (1966: 55) to mystic sects in Germany. He noted that groups such as the Scourging Friars and the Lollards were a latent bed of unrest, perpetuating a revolutionary tradition in times of suppression.

We do have documentation to support the conjecture of a Nian-White Lotus link on this organizational level. In terms of primary references, there are several accounts included in the materials on the Nian published in Shanghai in $1953 .^{5}$ A description by Huang Jun-cai notes that areas of Anhui (Anhwei) and Henan (Honan) harbored remnants of the White Lotus party who "plundered mercilessly" throughout the region. Because they dyed their whiskers red, they were called the "red-bearded bandits" (hong hu fei), each group (gu) of 
which was termed a "nian." Small "nian" might be composed of a few individuals or several dozen. Large "nian" numbered in the hundreds. When harvests were plentiful, the bandits were scarce. In bad years the Nian were everywhere.

A section of the "Annals of Henan Military Affairs" (Yujun jilue, 1953) provides another connection between the Nian and White Lotus. A description is given of "Golden Tower Fort," a small village in northern Henan. The leader of this village, Gao Yung-qing, was a White Lotus adherent, as his ancestors had been for three generations. When insurgency developed on the North China plain, some of Gao Yung-qing's followers joined up with the Nian rebels in Anhui.

Before long, the leader of the Nian's Eight Diagrams banner, Liu Gou, decided to pay a visit to Gao's stronghold. Receiving a very courteous welcome, Liu agreed to spare Golden Tower Fort from Nian destruction. In consequence, the local populace flocked to Gao Yung-qing's protection. There was to be an eclipse on August 1, 1861. Declaring this an auspicious omen, Gao determined to stage an uprising on the date. He plotted with various Nian leaders to launch a joint attack upon a nearby village. The news leaked out, however, and the would-be rebels were forced into retreat. After repeated encounters with the enemy, Gao was killed in battle and his sister-in-law succeeded him as commander of Golden Tower Fort.

These accounts suggest that White Lotus followers constituted a source of recruits for the Nian movement. The story of Golden Tower Fort illustrates a fundamental technique of Nian expansion-incorporation of whole communities whose leaders pledged allegiance to the rebellion. The historian Qian Hong relates another incident where a White Lotus community was of great assistance to the rebellion. In December 1857, a White Lotus adherent from Henan joined forces with the Nian in a series of uprisings in the Henan-Shandong area.

\section{OTHER ARGUMENTS FOR A WHITE LOTUS-NIAN CONNECTION}

Many historians of the Nian movement have asserted the existence of the Nian-White Lotus tie on other grounds as well. 
Chiang Siang-tseh, author of The Nien Rebellion, has suggested a number of links to the secret society. First, the Nian dyed their beards red, which was the favored color of the White Lotus Sect. We have seen how White Lotus rebels at the close of the Yuan dynasty wore red turbans and referred to themselves as the Red Army. Chiang points out that this practice of wearing red turbans was revived in the early stage of the Nian Rebellion. Furthermore, the White Lotus developed an art of fighting which Chiang states was imitated by the Nian half a century later. ${ }^{6}$ Nian military organization, the banner system, can also be traced to the White Lotus Society, and to a branch of the Society, the Eight Diagrams Sect. This connection with a secret society Chiang sees as an important factor distinguishing the Nian from ordinary bandits. Their affiliation with the White Lotus provided the Nian with a greater social awareness than that possessed by simple bandits (Chiang, 1954: 10-13).

Teng Ssu-yu (1961) draws a somewhat more complicated, chronological relationship between the Nian and the White Lotus. The Nian, Teng proposes, went through three stages of development. Initially they appeared in the 1790 s as remnants of the White Lotus Society. Then from 1806 to 1815 they plundered as red-bearded bandits. Finally they developed into an organized rebellion, known as the Nian. The practice of sworn brotherhood and use of the Eight Diagrams flag were, according to Teng, examples of the continuing influence of the White Lotus upon the rebellion.

Several published Nian folk tales also suggest White Lotus influence. The Eight Diagrams ( $b a$ gua) Sect was a major offshoot of the White Lotus Society, especially active in the Huai valley. In a 1962 collection of Nian folk stories there appears one tale dealing with the construction of an "Eight Diagrams Fort" in North Anhui (Nian jun gushi ji, 1962: 106-108). According to the tale, this fort, commanded by the Nian leader Gong De, was designed in an Eight Diagrams pattern. There were sections corresponding to the eight categories of heaven, earth, wind, thunder, water, fire, mountain, and swamp. Ditches were dug and walls erected in accordance 
with an yin-yang design. The maze of ditches and walls was so complex that one had to know the secret marks in order to find one's way about the fort.

Another folk tale describes the Red Children's Army (hong hai jun) which was said to include about 800 youths under the personal direction of Zhang Le-xing (Nian jun gushi ji, 1962: 183-195). These children, who wore red turbans, were primarily expected to help in building up the morale of the regular soldiers. They might also be put in charge of home defense when the troops were off on expeditions. One is tempted to draw a connection here again to the White Lotus Red Army of late Yuan days.

Nian folk stories suggest an important role for women, another possible legacy of White Lotus influence. One Nian tale recounts the exploits of a Ms. Cai, wife of Nian leader Liu Yung-qing, renowned for her martial skills and wily stratagems. Left at home once when the main village force was away on a plundering expedition, Cai is described as having repulsed a Qing attack with but a single cannon ball (Nian jun gushi ji, 1962: 148-150). In another story, a women's cavalry unit rescued Nian men stranded on the west banks of the Grand Canal. Masquerading as a funeral cortege, the women devised a successful plot for evading the imperial troops (Nian jun gushi ji: 255-258). A Nian song entitled "Respected Sister Li" presents this chivalric image (Alley, 1962: 42-43):

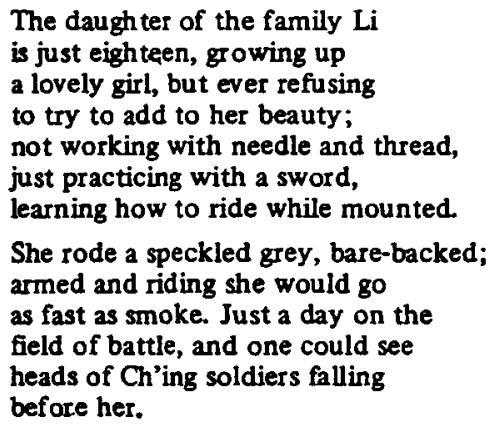

Like the women knights-errant, or xia nü, of bygone centuries, Nian heroines of popular tradition are invariably depicted as skilled in riding and swordplay. 
This image of active heroines is somewhat substantiated by scattered references in official documents. One such account (Zhang Rui-xi, 1953: 305-308) tells of a certain Liu San-gu, daughter of a biscuit seller in Huaiyuan. Beautiful and carefree, she attracted the attention of the bandit Zhang Long when he went to her father's shop to drink wine. Zhang had originally been in charge of training a self-defense force in the area, but after he became involved in a dispute with a local notable, he decided to lead his several thousand men west to join the Nian. He captured Liu San-gu, forcing her to accompany him. Being an adaptable sort, Liu resolved to make the best of her plight and began to practice horseback riding. She became an outstanding member of the Nian cavalry, greatly feared by the Qing military.

Another official document (Shu qiu da dao, 1953: 372) makes reference to the concubine of the Nian leader Ren $\mathrm{Zhu}$. Good at wielding a spear while on horseback, she assisted the Nian in battle. Yet another official source (Du Song-nian, 1953: 391-392) describes the women in rebel villages as unusually fierce. Whenever government troops appeared, these women, armed with bamboo brooms and metal spades, killed fearlessly. Thus women do seem to have played an important role in the Nian Rebellion, as was traditional in White Lotus movements.

The most convincing proponent of the theory linking the Nian and White Lotus is the historian Jiang Di (1959). In broadest terms, Jiang holds that the history of the Nian movement should be divided into two major periods. The first period (1808-1853) is characterized by the activity of the Nian Party (dang), while the second period (1853-1868) is characterized by the activity of the Nian Army (jun). The Nian Party was the forerunner of the Army, yet there were distinct differences between the two. The former was a political movement, the latier an uprising. The Nian Party was a variation of the White Lotus; the Army was an ally of the Taipings. Jiang traces the antecedents of the Nian back as far as the seventeenth century, to the activities of secret societies in the Jiangsu (Kiangsu)-Anhui-Shandong-Henan border region. 
Around the year 1808 these disparate groups merged to form the Nian Party.

The original home of the Nian, the north shores of the Huai River, had been the base of the White Lotus at the end of the Yuan dynasty. The Nian were closely connected with the 1796-1804 White Lotus Rebellion. The earliest members of the Nian, according to Jiang, included some White Lotus adherents who had survived the White Lotus Rebellion, as well as some former North Anhui braves who had been disbanded in the aftermath of the fighting. The White Lotus and Nian Party also cooperated in an uprising led by Zhu Feng-ge and Xing Ming-zhang in 1822. With the failure of this revolt, both Nian and White Lotus members went underground for a period (Jiang, 1959).

When the Nian Army emerged a generation later, Jiang notes a continuation of links to the White Lotus. In 1855, Zhang Le-xing was proclaimed leader of the movement and honored with the title of da Han ming ming wang, or Bright Commanding King of the Great Han. White Lotus leaders had also been termed ming wang or Bright King. Furthermore, some individual Nian Army leaders maintained a double identity as members of the White Lotus. This was the case with Liu Gou, leader of the Eight Diagrams banner.

Jiang $\mathrm{Di}$ does, however, recognize significant differences between the Nian and the White Lotus. Most important, the Nian Army was not a secret, underground group but an openly anti-Qing movement. The Nian were not a religious society. While the White Lotus used religion to organize the masses and had a tight, hierarchical leadership, the Nian had neither sacred texts nor a unified organization. Their only creed was the chivalrous code of stealing from the rich to aid the poor.

\section{ARGUMENTS AGAINST WHITE LOTUS-NLAN TIES}

A systematic refutation of the alleged connection between the Nian and White Lotus has been presented by members of the Anhui University History Department. In 1959 a group of 
scholars in northern Anhui conducted documentary and field research on the Nian Rebellion. Their findings are written up in a most informative article in the Anhui History Bulletin (Anhui shixue tongxun, 1959). First of all, these authors attribute some of the confusion to a misunderstanding over the term used to refer to Nian leaders. Nian leaders, they explain, were called tang $z h u$, or journey leaders, the character tang being an auxiliary noun for verbs meaning to walk, to journey, and the like. Many Qing documents incorrectly wrote a homophone for the character tang, with the quite different meaning of a religious meeting place. It was thus easy for scholars to misunderstand the tang $z h u$ as religious leaders and to identify them with the White Lotus Society. Actually, according to this article, the term tang $z h u$ was originally used to refer to the chiefs of salt smuggling expeditions. Since many of the Nian leaders had previously engaged in salt smuggling in the Huai valley, it was natural for the term to be extended to refer to leaders of Nian plundering forays.

Furthermore, these Anhui scholars quarrel with the identification of "red beards" with the Nian. According to their field work, the term "red beards" was simply a term applied to bandits in the North Anhui area. The epithet was used by the government as a blanket label for all unruly elements in the region.

On this point, it is interesting to refer to the account of an official who was a contemporary of the Nian, Fang Yu-lan. According to Fang, the origins of the Nian can be traced back to the Jia-qing period (1796-1820). With the conclusion of the White Lotus Rebellion, braves were repatriated to their native homes. Military experience had accustomed these men to a life of violence and plunder, and when they returned home they scorned regular employment and spent their days gambling and drinking. With successive crop failures in the Huai Valley, the local unemployed began to attach themselves to these former braves. Together they milled about the market places by day and robbed villages by night. When the matter was raised with local officials, a verdict was handed down which stated that 
since these ruffians came in the dark and left at dawn, their crime was less severe than that of robbers. Thus they escaped punishment and grew increasingly daring. They began to carry weapons in broad daylight, attacking villages, killing, and raping. At night they blackened their faces and reddened their beards to escape recognition. They thus came to be popularly known as the hong huzi or Red Beards.

This account, to the degree to which it is credible, suggests something of a negative relationship between the Nian and White Lotus. The initial recruits of the Nian movement were not White Lotus adherents, but rather individuals who had fought on the government side in suppressing the rebellion. According to Jiang $\mathrm{Di}$, of course, such elements were not necessarily anti-secret-society or anti-revolutionary. Being of peasant background, these people could rapidly change from a tool of the ruling class into a positive anti-Qing force. This bears similarities to the situation after the suppression of the Taiping movement when dismissed braves of Zeng Guo-fan's Xiang army entered the Elder Brothers Society.

The historians from Anhui University also cast doubt upon Jiang Di's contention that because North Anhui was the base of the White Lotus, the Nian borrowed White Iotus flags, titles, fighting experience, slogans, and uniforms. Geographical coincidence is insufficient evidence of a solid connection between the two movements, they insist. These scholars do agree with Jiang that if Zhang Le-xing were really called Bright Commanding King of the Great Han that this would resemble a White Lotus title. However, reference to this title appears in only one available document, the "Annals of Henan Military Affairs" (Yujun jilüe, 1953). In field investigation, it was ascertained that old people in North Anhui knew of Zhang only as Alliance Leader (meng $z h u$ ) or Great Han Alliance Leader (da Han meng zhu) and had never heard of the Bright Commander part of the title. ${ }^{8}$ According to the Anhui University scholars, the Nian slogan of "carry out the will of Heaven; kill the rich and aid the poor" also suggests something other than a White Lotus inheritance. This creed, they note, was more in the tradition of 
Water Margin (Shui hu zhuan) banditry than a secret society legacy.

\section{REASSESSMENT AND CONCLUSION}

Thus we see that the question of Nian-White Lotus connections has been a controversial one among Chinese historians. The paucity of primary materials for either the White Lotus or the Nian means that evidence on both sides of the controversy is circumstantial at best. Still the importance that such a linkage would have had calls for an assessment of the arguments.

The connection between the Nian and White Lotus is not clearly evident. Yet on the whole the assertion of some linkage appears plausible. Perhaps the most persuasive clue lies in the Nian organizational system. The use of five colored banners, corresponding to the five elements of Chinese alchemy, was an institution in the White Lotus Society. The further addition of a special Eight Diagrams banner points even more conclusively to an imitation of White Lotus precedents. The leader of this banner, Liu Gou, effected an alliance with White Lotus adherents in Henan, further strengthening the argument for a linkage.

It thus seems likely that individual Nian leaders were affiliated with the secret society and that their presence in the rebellion was a powerful incentive for the adoption of certain White Lotus practices. While the research of the Anhui University historians cannot be dismissed lightly, one has the suspicion that their stand against a White Lotus connection stems as much from regional pride as from solid documentation. Even so, it is certain that the Nian were in no way a carbon copy of the White Lotus Society.

Any widespread peasant revolt in China necessarily drew upon a number of organizational sources. While secret societies constituted an important reservoir of strength for potential insurgencies, they were by no means the only such source. Equally important, for example, were the more "orthodox" local self-defense forces (tuanlian or lianzhuang hui). In 
response to expansion of the Taipings in 1855, communities north of the Huai River erected earth walls and began to recruit and train self-defense units. While these groups were originally intended as protection against the approaching rebels, they also became potential sources of Nian support. If leaders of these local corps were converted to the side of the rebellion, then whole communities could be enlisted in the Nian cause. There are numerous instances of such units joining the rebel side. These groups and their fortified bases played a pivotal role in the struggle between the Nian and the government.

In addition to secret society and self-defense-force links, the Nian relied on kinship as an organizational support. Clans served as a major basis of recruitment for the movement. In the Nian army, those surnamed Zhang were generally under the yellow banner of Zhang Le-xing; those named Hou were with the red banner; those by the name of Liu were associated with the blue and Eight Diagrams banners. A very strong localist orientation developed in which many members of the Nian were almost exclusively committed to protecting their own family units, with little conception of a larger collective. The Nian were like a myriad of independent kingdoms, each unit having its own fort, soldiers, and guards.

Agriculture in traditional China was organized around the household unit. The nuclear family was thus the center of peasant economic and social activity. The significance of secret societies, self-defense forces, and clans lay in their ability to expand the horizons of peasant cooperation beyond the simple household. These larger associations, while quite different in their membership and goals, shared a capacity to widen the level of peasant political participation. For this reason they constituted crucial bases of support for any large-scale movement in the area.

These local organizations were important to subsequent uprisings in the Huai valley as well. The Boxers and Red Spears relied heavily on secret society, defense corps, and kinship support. Communist organizing in the area was initially also dependent upon these bases. As is well-known, individual 
leaders in the Communist movement (for example, Zhu De and He Long) had secret society affiliations. In addition, there is mention in Huaibei inner-Party documents (Wang and $\mathrm{Li}, 1943$ ) of the need to utilize secret societies (such as the San fanzi) as one power base during early mobilization. A Kuomintang intelligence report (Dangpai, 1940) noted that the New Fourth Army in Anhui had been especially patient toward the Red Spears, Big Knives, and local self-defense units issuing instructions not to insult members or leaders of these groups. In April 1938, Communist self-defense forces in Shandong united with local Red Spears to repulse a Japanese advance ( $\mathrm{Ki} \mathrm{Yu,} \mathrm{1938).}$ The Communists aimed ultimately to absorb the membership of these associations into their own forces. According to KMT figures, by 1940 the New Fourth Army had successfully recruited $75 \%$ of the self-defense corps members, $43 \%$ of the Big Knives, and numerous Red Spears in Anhui (Dangpai, 1940).

Initially the Communists even used the traditional baojia system as a method of rural control in parts of the Huai valley (Wu Zhen-lu, 1944). The baojia relied upon the household as its organizational unit. Thus if the head of a household committed a crime, all family members were deprived of community protection. Communist reports at the time recognized that there must be a switch from the family unit to the individual citizen (gongmin) if democracy were to be fully realized.

Kinship was sometimes also used as a means of mobilizing the peasantry. Communist reports frequently mention the importance of ganqing, or emotional feeling, as an ingredient in the establishment of mutual aid teams and other cooperative ventures. One obvious source of such emotional ties was kinship. A first hand report (Yang Yuan-zhang, 1944) of the development of militia in one Anhui village suggests the usefulness of family ties in successful mobilization. Of seven members of the Military Affairs Committee, all but the chairman shared the same surname. Four out of eight village militia leaders also had the same surname. Yet at the same time there was a recognition of the need to popularize the militia and 
to prevent them from assuming non-military responsibilities such as tax collection. Above all, reports (Deng Zi-hui, 1943) stress that the militia must not become like self-defense forces of old (min tuan hua). Thus, while the Communists initially relied upon many of the same bases of support utilized by earlier peasant movements, the Communist revolutionaries were at the same time anxious to effect a qualitative transformation of these "feudal" institutions.

Secret societies do indeed seem to have served an important role in providing continuity to the mobilization of peasant revolt in the North Huai valley. Evidence can be garnered to verify the existence of such a link between the White Lotus and the Nian Rebellion. The importance of the tie, however, appears to lie less in ideology or rituals than in the fact that the White Lotus Society constituted a source of organized recruits. Peasant revolt in China did exhibit striking continuities in both geographical location and organizational structure. The reason for such continuity, we may hypothesize, was the existence in certain regions of readily mobilizable local associations-secret societies, self-defense forces, clans, and the like. Inciting these essentially passive and protective units into active revolt was the sine qua non of a large-scale rebellion. And, as the Communist movement demonstrates, the eventual supplanting of these bases of peasant organization was required for genuine revolution.

\section{NOTES}

1. This calls attention to a very different form of socialization from the Confucian model proposed by Solomon (1971).

2. A general collection is contained in Zhongguo nongmin qiyi di gushi (Stories of Chinese peasant uprisings), Shanghai: Huadong renmin chubanshe, 1952. See also Rewi Alley (1962). On the Nian Rebellion, see Li Tong-shan et al (eds.), Nian jun geyao (Songs of the Nian Army), Shanghai: Wenyi chubanshe, 1960. Also see Nian jun gushi $\ddot{j}$ (1962).

Boxer tales may be found in A Ying (ed), Gengzi shibian wenxue $i i$ (A literary collection on the Boxer Incident), Peking: Zhonghua shuju, 1959. A Ying (pen name of Qian Xing-cong, an authority on Chinese popular literature of this century, gathered literary records as part of the organized effort to provide a new interpretation to Chinese history. Another selection of Boxer stories appeared in the 
magazine Minjian wenxue (Folk literature), April, November, December 1958; February, March, December 1959.

3 Cohen further points out (1963: 123) that Christianity was, as a result of the Yung-qing emperor's Sacred Edict, closely associated in the minds of many Chinese with that most subversive of secret societies, the White Lotus Sect.

4 The story of this Nian myth also appears in Zhang Wen-qing, Nian dang qiyi (1953) The closeness in wording suggests that Fan Wen-lan relied upon this account for his information. Unfor tunately no reference is cited by $Z$ hang either.

5 This series has been reprinted in Taiwan as a six volume set entitled Nian jun wenxian huibian (A collection of documents on the Nian Army), edited by Yang Jia-luo, Taibei (Taipei): Dingwen shuju, 1973. Pagination is identical to the original mainland edition.

6 By contrast, Luo Er-gang (1939) suggests that the mobile warfare of the Nian Army can be attributed to the genius of the Taiping leader Lai Wen-guang who joined the Nian in 1864.

7. All descriptions of women's involvement in the Nian stress their skill in horseback riding The use of cavalry may have enabled women, who otherwise would have been impeded by their bound feet, to engage in battle alongside men. Female participation in the Taiping movement has often been attributed to the fact that Hakka women were not subjected to the brutal practice of footbinding. On the North China plain it seems plausible that horses permitted mobility and hence the possiblity of active warfare by women who did have bound feet.

8. Further light on the question of Zhang Le-xing's title is shed by the discovery of two primary documents from the Nian movement-the self-confession of Zhang Le-xing and a proclamation by Zhang to the Nian in North Anhui Both documents were reprinted in Guangming ribao of October 10, 1962, p. 4. In the self-confession, Zhang refers to himself as "da Han yong wang" or "Great Han Eternal King." In the proclamation he terms himself "da Han meng zhu," or "Great Han Alliance Leader." Thus neither the Jiang Di nor the Anhui University theory is upheld by these documents. However, from references in local gazetteers, there is ample support for the Anhui scholars' position that Zhang was popularly referred to simply as Alliance Leader. A distinction may be made between the more exalted titles which $Z$ hang himself uses and those by which he was commonly known.

\section{REFERENCES}

ALLEY, R. (1962) Poems of Revolt. Peking: New World Press

Anhui shixue tongxun (1959) (Anhui history bulletin) General Series 14

CHIANG SIANG-TSEH (1954) The Nien Rebellion Seattle: Univ. of Washington Press.

CHU, R.Y D. (1967) "An introductory study of the White Lotus Sect in Chinese history with special reference to peasant movements." $\mathrm{Ph} . \mathrm{D}$. dissertation. Columbia Univ.

COHEN, P. A (1963) China and Christianity Cambridge: Harvard Univ. Press.

Dangpai diaocha zhoubao (1940) (Party intelligence weekly) 20.

DENG ZI-HUI (1943) "Huaibei gaoganhui shang di fayan" (Speech to the Huaibei senior cadres conference), Fuxiao (Dawn) 3 (June): 16. 
DU SONG-NIAN (1953) "Zhi Feizhai suoji" (Notes from Zhi Fei study) in Fan Wen-lan (ed.) Nian jun, I: 391-392.

ENGELS, F. (1966) The Peasant War in Germany. New York: International Publishers.

FAN WEN-LAN [ed.] (1962) Zhongguo jindai shi (Modern Chinese history). Peking: Renmin chubanshe.

--- (1953) Nian jun (The Nian Army). Shanghai: Renmin chubanshe

FANG YU-LAN (1953) "Xinglie riji huiyao" (A selective diary) in Fan Wen-lan (ed), Nian jun, I: 309-314.

HARRISON, J. P. (1969) The Communists and Chinese Peasant Rebellions. New York: Atheneum.

HUANG JUN-ZAI (1953) "Jinhu qimo" (Seven impressions) in Fan Wen-lan (ed), Nian jun, I: 377-378.

HUDSON, J. (1928, 1929) "Chinese secret societies," China Journal 9, 4 (October 1928): 164-170; 9, 5 (November 1928): 215-221; 9, 6 (December 1928): 276-282; 10, 1 (January 1929): 12-16.

JIANG DI (1959) Chuqi Nian jun shi luncong (Essays on the early history of the Nian Army). Peking: Sanlian shudian.

- - (1956) Nian jun shi chutan (A preliminary investigation of the history of the Nian Army). Peking: Sanlian shudian.

LI YU (1938) "Shandong kangri youji zhanzheng di fazhan" (The development of anti-Japanese guerrilla warfare in Shandong), Jiefang (Liberation) 43 (August): 11-12.

LUO ER-GANG (1939) Nian jun di yundong zhan (Mobile warfare of the Nian Army) Changsha: Shangwu yinshu guan

Nian jun gushi ji (1962) A collection of stories from the Nian Army). Shanghai: Wenyi chubanshe.

QIAN HONG (1950) "Nian jun-Taiping tianguo shiqi beifang di nongmin yundong" (The Nian Army-a northern peasant movement during the time of the Taipings) in Taiping tianguo geming yundong lunwenji (Essays on the Taiping revolutionary movement): 120-135. Peking: Sanlian shudian.

REDFIELD, R. (1956) Peasant Society and Culture Chicago: Univ of Chicago Press.

"Shu qiu da dao" (1953) (Big Knife Shu) in Fan Wen-lan (ed ), Nian jun, VI: 372

SOLOMON, R. (1971) Mao's Revolution and the Chinese Political Culture Berkeley: Univ of California Press

TENG, SSU-YU (1961) The Nien Army and their Guerrilla Warfare, 1851-1868 Paris: Mouton

WANG GUANG-YU and LI REN-ZHI (1943) "Silingsui qunzhong gongzuo di xianzhuang yu jingyan" (The current condition and past experience of mass work in Silingsui), Fuxiao (Dawn) 5 (October 1): 35-42.

WU ZHEN-LU (1944) "Zhuhu qunzhong chujian yundong" (The mass movement to weed out wicked elements in Zhuhu), Fuxiao (Dawn) 9 (March 10): 49-60.

YANG YUAN-ZHANG (1944) "Chenyu xiang minbing gongzuo" (Militia work in Chenyu xiang), Fuxiao (Dawn) 9 (March 10): 37-48

"Yujun jilüe" (Annals of Henan military affairs) in Fan Wen-lan (ed), Nian jun, I: $377-378$

ZHANG RUI-XI (1953) "Lianghui kanluan ji” (Records of suppression of revolt in the Huai region) in Fan Wen-lan (ed), Nian jun, I: 305-308.

ZHANG WEN-QING (1953) Nian dang qiyi (The uprising of the Nian Party). Shanghai: Huadong renmin chubanshe. 